\title{
PEMEROLEHAN FONOLOGY PADA ANAK USIA DUA TAHUN DUA BULAN (Studi Kualitatif Pemerolehan Fonology Pada Aisyah)
}

\author{
HERLINA \\ Fakultas Ilmu Pendidikan Universitas Negeri Jakarta \\ Email : herlina.unj.id@gmail.com
}

\begin{abstract}
The purpose of this research was to determine the development of information acquisition phonology elements (vowels and consonants) in children two years and two months aged. Particular regarding Aisyah phonology development in language development in their family life. This research was conducted on a family has a background of adequate economic life. Based on the results of the research to analyze the data in this research, there are some steps of that; 1) acquisition phonology children two years and two months aged in particular on already mastered all vowel sounds. 2) In the consonant sounds had started well when positioned at the beginning of the word are in the middle of the word and the end of the word. 3) Acquiring phonology of the consonant sounds can be uttered by showing the activities carried out in family activities. 4) In the following the activities of his family, Aishah is very active so she was able to utter the words that fit what she saw with the actual facts, and (5) The acquisition of phonology close related to the acquisition of the lexicon. The data showed that there are sounds that arise because it mimics speechs children and emerge as an activity often done so had never experienced it. Sounds found in this study to be a part of the acquisition phonology received by children from the surrounding neighborhood, although small influence will be seen that the environment plays an important role in the acquisition and the ability neurophysiological phonology children themselves.
\end{abstract}

Keywords: Acquisition phonology, vowels and consonants, family environment.

\begin{abstract}
Abstrak : Tujuan penelitian ini adalah untuk mengetahui informasi perkembangan pemerolehan unsur-unsur fonologi (vokal dan konsonan) pada anak usia dua tahun dua bulan khususnya menyangkut perkembangan fonologi Aisyah di dalam kehidupan keluarganya. Penelitian ini dilakukan pada satu keluarga yang mempunyai latar belakang kehidupan ekonomi yang memadai. Berdasarkan hasil penelitian, untuk menganalisis data dalam penelitian ada beberapa tahap yang dilakukan yaitu ; 1) pemerolehan fonologi anak yang berumur dua tahun dua bulan khususnya pada bunyi vokal yang sudah dikuasai semua, 2) pada bunyi-bunyi konsonan sudah mulai baik apabila berada diawal kata, berada pada tengah kata maupun berada pada akhir kata, 3) pemerolehan fonologi pada bunyi konsonan yang dapat diujarkan dengan memperlihatkan aktivitas-aktivitas yang dilaksanakan didalam kegiatan keluarganya, 4) di dalam mengikuti aktivitas keluarganya, Aisyah sangat aktif sehingga dia mampu mengucapkan kata-kata yang sesuai dengan apa yang dilihatnya dengan fakta yang sebenarnya, (5) pemerolehan fonologi berkaitan erat dengan pemerolehan leksikon, sehingga diperoleh data bahwa ada bunyi yang muncul karena meniru ucapan orang dewasa dan muncul karena suatu kegiatan yang sering dilakukan sehingga sudah pernah mengalaminya. Bunyi-bunyi yang ditemukan dalam penelitian ini menjadi bagian dari pemerolehan fonologi yang diterima anak dari lingkungan sekitarnya, meskipun kecil pengaruhnya akan terlihat bahwa lingkungan sangatvberperan penting dalam pemerolehan fonologi dan kemampuan neurofisiologis anak itu sendiri.
\end{abstract}

Kata kunci: Pemerolehan fonologi, bunyi vokal dan konsonan, lingkungan keluarga. 
Salah satu kajian yang menarik dalam psikolinguistik adalah proses pemerolehan bahasa yang terjadi pada anak yang baru mulai belajar bahasa. Pengkajian pemerolehan bahasa dapat dilakukan terhadap perkembangan pemerolehan aspek-aspek bahasa. Pemerolehan bahasa dikaji oleh berbagai ahli dari disiplin ilmu yang berbeda-beda. Tujuan pengkajian ini dilakukan untuk mengetahui sejauh mana pengetahuan pengembangan teori tata bahasa dan teori belajar bahasa dalam kaitannya pemerolehan fonologi. Penelitian tentang pemerolehan bahasa sudah banyak dilakukan dengan objek bahasa yang berbeda. Tujuan utamanya adalah menemukan prinsip-prinsip yang memungkinkan anak memperoleh aturan-aturan bahasa secara bertahap sebelum memperoleh tata bahasa bagi orang dewasa yang sempurna.

Langkah-langkah di dalam proses pemerolehan bahasa terhadap anak usia dua tahun dua bulan adalah sesuatu yang menarik untuk dikaji. Untuk itu para ahli linguistik banyak yang meneliti terkait pemerolehan bahasa anak. Saat ini penelitian pemerolehan bahasa adalah salah satu kajian untuk mengetahui bagaimana perkembangan bahasa anak mulai dari umur dua tahuan dua bulan. Menurut David Ingram (1998), Fonology shows a much more varied pattern of disoreder with deviant as well as delayed system commonly seen, and some children develoving phonologies which are quite different from the target phology and from normally developing phonologies. Difficulties are not restricted to single area, but occur in a variety of areas of the phonology. Berdasarkan teori Ingram bahwa fonologi menunjukkan pola yang jauh lebih bervariasi dengan adanya sistem yang biasa terlihat dalam pemerolehan fonology anak, dan beberapa anak mengembangkan pemerolehan fonologinya cukup berbeda dari target morfologi dan dari biasanya dalam berkembang fonologi. Kesulitan ujaran tidak dibatasi pada satu bagian ujaran, tetapi terjadi dalam berbagai bidang fonologi. Disamping itu Chomsky (1975) mengemukakan bahwa; 
Pemerolehan Fonology ...

Herlina

has determined that being

biologically prepared to acquire

language regardless of setting is

due to the child's language

acquisition device (LAD), which

is used as a mechanism for

working out the rules of

language. Chomsky believed

that all human languages share

common principles, such as all

languages have verbs and

nouns, and it was the child's task

to establish how the specific.

$L A D$ already contains the

concept of verb tense and so by

listening to word forms such as

"worked" or "played". The child

will then form a hypothesis that

the past tense of verbs are

formed by adding the sound

$/ d /, / t /$ or /id/ to the base form.

Chomsky percaya semua bahasa manusia secara umum memiliki kata kerja dan kata benda yang digunakan untuk mengungkapkan prinsip-prinsip yang mendasari misalnya Language Acquisition Device ( LAD) yang berisi konsep-konsep kata kerja dengan mendengarkan bentuk kata seperti 'bekerja atau' dimainkan anak itu kemudian akan membentuk hipotesis bahwa bentuk lampau dari kata kerja dibentuk dengan menambahkan suara /d/, /t/ atau /id/ ke bentuk dasar.

Menurut Kuhl (2008); untuk memperoleh bahasa, anak-anak harus menemukan perbedaan fonetik yang akan digunakan dalam budaya bahasa mereka dan melakukannya dengan diskriminasi antara hampir semua unit fonetik bahasa di ketahui. Selama tahun pertama kehidupan anak, anak mulai memahami ujaran dengan membentuk peta persepsi dari ujaran mereka dari apa yang didengar di lingkungan mereka. Penelitian Kuhl difokuskan pada mekanisme yang mendasari transisi perkembangan fonologi anak dari kapasitas fonetik universal yang merupakan diskriminasi fonetik asli. Di dalam pemerolehan bahasa terkait dengan pemerolehan sintaksis, semantik, dan pemerolehan fonology. Bagian-bagian bahasa tersebut diperoleh dan berkembang secara bersamaan, walaupun didalam pembahasannya bagian-bagian bahasa itu dapat dikerjakan secara terpisah. Di dalam penelitian ini dikaji tentang perkembangan pemerolehan bahasa 
khususnya perkembangan fonologi anak berusia dua tahun dua bulan yang bernama Aisyah. Banyak hal yang dapat diidentifikasi dalam pemerolehan bahasa yakni pemerolehan bahasa dengan melihat perkembangan gramatika, fonologis, semantik sintaksis serta perkembangan pragmatik. Dalam penelitian ini mengkaji "Bagaimana perkembangan pemerolehan bahasa anak khususnya pemerolehan fonologi anak berusia dua tahun dua bulan"?

Di dalam kajian psikolinguistik menurut Gleason and Ratner (1998), membahas tiga hal yang sangat penting dalam pemerolehan bahasa anak; 1) bagaimana orang memahami proses di dalam berbicara dan menulis dalam suatu bahasa. (comprehension), 2) bagaimana orang menghasilkan bahasa yang mudah untuk dipelajari dari hasil ujaran dan dapat menggunakan stimulasi bahasa untuk menganalisis bentuk kesalahan, bagaimana merespon ujaran yang didengar. Namun lebih sulit untuk mendapatkan wawasan tentang bagaimana konsep yang dibentuk dalam bahasa, dalam proses umumya tidak nampak dalam observasi, dan bentuk ekspresi pembicara bahkan dalam menanggapi respon menimbulkan apa yang dikendalikan (production), 3) bagaimana manusia atau anak belajar bahasa pertamanya (first language) atau pemerolehan (acquisition)

Pemerolehan bahasa secara tradisional menurut David Ingram (1989: h. 7); divide the four stages in language acquisition is divided into four periods: First, the development of prelinguistic which starts from birth until the end of the first year. Second, the utterance of the words around the age of one year to 1.5 years. Third, the combination of the words first, example from about 1.5 years to 2 years. Fourth, simple and complex sentences that began 3 years of age, language acquisition into 5 stages namely: First, the preliminary stage (the first year). This stage is characterized by three types of behavior imitate and a preliminary understanding. Second, the first period (1.0 to 1.6 years). In this period children acquire a sound with special meaning that expresses the idea of a sentence as a whole, but there is no evidence that children understand grammar. Third, the second period (1.6 
Pemerolehan Fonology ...

Herlina

to 2.0). At this stage the child realizes that everything has meaning with successive bursts in acquiring words, the question of the object's name. Berdasarkan teori Ingram bahwa pemerolehan bahasa anak diikuti oleh perkembangan pralinguistik yang dimulai sejak lahir sampai pada usia satu tahun. Mulai tahun kedua anak dapat menuturkan satu dan dua kata sampai pada umur satu setengah tahun, kemudian gabungan kata dapat diujarkan pada umur satu setengah tahun sampai pada umur dua tahun. Ketika anak berumur dua tahun anak semakin menyadari bahwa kata-kata yang diujarkan mempunyai makna dalam pemerolehan kata dan dapat membuat pertanyaan - pertanyaan tentang nama - nama benda yang ada disekitarnya. Fletcher and Garman (1985; h.342) mengemukakan dasardasar pemerolehan bahasa dari beberapa teori linguistik yang berhubungan dengan bentuk pemerolehan bahasa anak yang berusia dua tahun dua bulan dengan bagian bagian yang penting yaitu; 1) Beberapa sifat dari bahasa manusia. 2) Tata bahasa universal dan penguasaan bahasa. 3) pemerolehan bahasa serta tata bahasa yang universal ; 4) pengetahuan tata bahasa sejak dini; 5) prinsip bentuk struktur kalimat; 6) mengembangkan tata bahasa.

Menurut Halliday and Vygotsky (dalam Soenjono 2000) In the field of lingistic language acquisition divided into two, first language acquisition and second language acquisition. The first language acquisition occurs when the child has never learned any language and acquire language. This acquisition can be monolingual (first language acquisitoon) can be two languages simultaneously or sequentially (multilingual). First language acquisition is obtained from the child's interactions with its environment, even if the child has the basic potential or devices, that potential will develop optimally after receiving stimulus from the environment. Bahwa dalam bidang linguistik pemerolehan bahasa dibagi dalam dua bagian, yaitu pemerolehan bahasa pertama dan pemerolehan bahasa kedua. Bahasa pertama anak memperolehnya ketika anak belajar bahasa apapun yang belum pernah diketahui sebelumnya. Bahasa kedua bisa diperoleh secara berurutan dengan 
bahasa pertama yang diperolehnya atau disebut multingual.

Sedangkan menurut Monks (2004; h.58), mengemukakan bahwa dari kalimat satu dan dua kata ini lambat laun akan berkembang menjadi kalimat tiga kata dan seterusnya, dari perkembangan inilah kehidupan berbahasa anak dibentuk menjadi anak yang memiliki kecerdasan linguistik yang baik. Dari kalimat dua kata itu, lambat laun berkembanglah tiga kata yang dalam arti struktural mula-mula masih mirip dengan kalimat dua kata, meskipun masih mirip dengan bentuk struktural namun segera terjadi suatu defirensiasi dalam kelompok kata-kata, suatu kecakapan verbal anak yang menyebabkan banyak kata-kata dimasukkan dalam klasifikasi baru sampai anak dapat mengatur kembali kata-kata dalam bahasanya.

Pembentukan jaringan otak terjadi sangat cepat, pada empat tahun pertama kehidupan anak, terutama otak kanan berkembang lebih dahulu melalui pendidikan. Melalui fungsi otak kanan berkembang kemampuan seperti: menyanyi, menari, menggambar dan bermain. Kelengahan perawatan dan stimulus yang diberikan orangtua pada masa tersebut tidak dapat dikejar dan digantikan selamanya. Oleh karena itu, pemberian nutrisi yang baik pada masa bayi akan sangat membantu perkembangan dan stimuli pendidikan dengan memberikan lingkungan yang kaya pengalaman, rangsangan terhadap sensorik motorik, dan keteladanan orangtua merupakan kebutuhan utama dalam rangka menyiapkan kualitas kehidupan anak. Cara perkembangan sistem yang kompleks inilah yang dapat berpengaruh terhadap pertumbuhan intelegensi, kepribadian, dan kualitas hidup seorang anak.

Kemampuan yang dikenal dengan kecerdasan selama ini hanya mengukur kemampuan kognitif semata. Kecerdasan ini bersifat menetap seiring dengan bertambahnya usia seseorang sampai sembilan belas tahun, kemudian mengalami penurunan terus-menerus dan akhirnya berhenti. Inteligensi adalah juga kapasitas mental untuk memproses informasi secara otomatis dan menunjukkan konteks perilaku yang tepat dalam menanggapi sesuatu yang baru. Feldman (1997; h.85), mengemukakan bahwa, kemampuan 
Pemerolehan Fonology ...

Herlina

dapat berkembang atau menurun bergantung kepada motivasi dan keadaan pengalaman serta pendidikan yang relevan yang terjadi pada diri seseorang. Gregory (2000; h. 78) mengemukakan bahwa intelligence is multiple innate abilities which serve as a range of possibillities; these abilities develop (or fail to develop, or develop an later atrophy) upon motivation and exposure to relevant educational experiences .

Penelitian Develping Early Literacy Report of the National early literacy oleh Scarborough (2008: h. 22) bahwa kemampuan membaca semestinya sudah dapat distimulasi sejak seseorang berada pada tahapan perkembangan usia dini. Hal ini sesuai dengan hasil riset yang dilaporkan oleh The National Institute for Literacy yang mengungkapkan bahwa awal perkembangan kognitif dan Linguistik, memprediksi prestasi kemudian bahkan jauh dikemudian hari. Selain itu, hasil riset Ilana Goodman dan Lesly Wade (2010: h. 1) yang meneliti tentang kepekaan pada tekanan linguistik, kesadaran fonologis dan kemampuan membaca awal pada anak-anak pra- sekolah, melaporkan hasil penelitiannya didalam Journal of Research in Reading. Hasil riset ini telah menemukan bahwa kepekaan terhadap tekanan linguistik berhubungan dengan kesadaran fonologis dan perkembangan kemampuan membaca.

Gleason dan Ratner (1998: h. 420-425) membagi tahap perkembangan membaca anak usia dini dalam dua tahap, yaitu: (1) Tahap protoliterasi. Pada periode ini kemampuan membaca yang ditunjukkan anak-anak berakar dari keterampilan berbicara. Munculnya keterampilan fonologi dan pengenalan huruf walaupun tidak seutuhnya, tetapi lebih sebagai sebuah variasi keterampilan. Proses pemerolehan membaca anak-anak membawa sejumlah keterampilan fonologi dan semantik.

Berkaitan dengan hasil penelitan tersebut, Dardjowidjojo (2000: h.21). Dalam komponen pemerolehan fonologi, bentuk sifat keabsolutannya sangat tampak dalam arti bahwa bunyi tidak mungkin dikuasai anak sebelum bunyi lain dikuasainya, meskipun kendala seperti ini tidak berlaku untuk seluruh bunyi pada bahasa tersebut. 
Dalam komponen sintaktik kecenderungan untuk bersifat absolut tampaknya kurang kuat, sedangkan dalam komponen semantik kecenderungan untuk bersifat universal ini sangat tipis.

\section{Pemerolehan Fonologi}

Dalam ilmu linguistik fonologi sebagai salah satu aspek yang terdapat didalamnya yang mempelajari tentang fonem serta bunyi-bunyi yang diucapkan anak sejak umur satu tahun yang akan dilihat sebagai bagian dari pemerolehan bahasa. Lyons (1995: h. 110) mengemukakan definisi umum tentang fonem yang dikemukakan bahwa ada dua bunyi yang secara fonetis berbeda dalam lingkungan yang sama yang sangat berpengaruh untuk membedakan kata-kata yang berlainan. Misalnya [1] dan [r] adalah masuk dalam fonem-fonem yang jauh berbeda dalam bahasa Inggris karena membedakan pasangan kata-kata. Misalnya: kata right dan light, lot dan rot. Didalam bahasa Indonesia beberapa hal yang dapat dilihat dalam kata-kata seperti: bambu dan rambu, tombak dan rombak, buku dan kuku dan sebagainya.
Perkembangan sistem fonologi anak-anak dimulai jika anak-anak dapat mengucapkan kata pertama dalam bahasa yang benar yaitu untuk menyampaikan arti. Dengan demikian pemerolehan sistem bunyi yang sebenarnya dimulai pada saat anak-anak mengucapkan kata pertama untuk tujuan komunikasi ketika anak - anak berusia kurang lebih 1 tahun. Menurut Ingram (1987; h.420) dalam pemerolehan fonologi setiap individu mempunyai variasi, yaitu: 1) variasi performance yang timbul berdasarkan keturunan dalam bentuk pilihan yang berbeda atau kemampuan perbedaan tipe belajar sehingga menentukan perbedaan diantara anak, 2) variasi lingkungan yang disebabkan oleh perbedaan dalam input pada anak yang berbeda, 3) variasi linguistik yang timbul dari sejumlah pilihan yang berbeda pada peranti pemerolehan bahasa yang menyediakan pemerolehan terutama jenis struktur. Dengan demikian jenis variasi individu dalam pemerolehan fonologi dipengaruhi berdasarkan ketiga variasi tersebut.

Jacobson dalam Dardjowidjojo (2000; h.21) mengatakan bahwa adanya 
Pemerolehan Fonology ...

Herlina

keuniversalan dalam bunyi-bunyi bahasa itu sendiri diperoleh secara berurutan dalam pemerolehannya. Anak memperoleh bunyi-bunyi itu melalui suatu cara yang konsisten dan pemerolehan bunyi pun berjalan serasi dengan kodrat bunyi itu sendiri.
Langkah awal yang dikeluarkan oleh anak adalah lawan kata antara konsonan dan vokal. Ada tiga vokal yang sifatnya universal artinya, ketiga bunyi vokal tersebut terdapat dalam bahasa manapun.

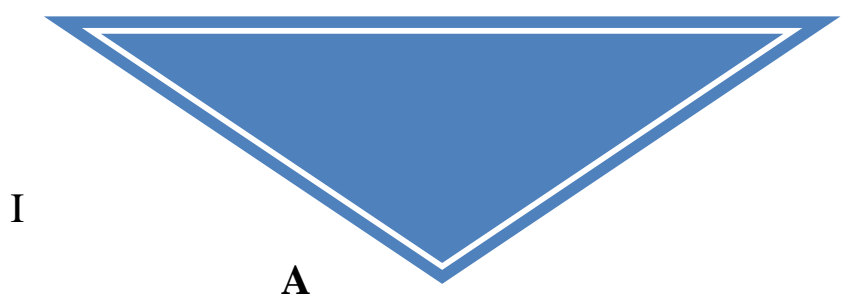

Gambar 1. Sistem vokal minimal; Jacobson dalam Soenjono (2000)

Menurut Jacobson bahwa inventori bunyi-bunyi dapat saja dibedakan dengan bahasa satu dengan bahasa lainnya tetapi berhubungan sesama bunyi itu sendiri mempunyai sifat universal. Hukum solidaritas Takterbalikkan Laws if Irreversible Solidarity yaitu:

1. Jika suatu bahasa mempunyai konsonan hambat velar (velar stops), maka bahasa tersebut tentu mempunyai konsonan hambat dental dan bilabial. Contoh: jika bahasa $\mathrm{X}$ mempunyai $[\mathrm{k}]-[\mathrm{g}]$, bahasa ini pasti mempunyai $[\mathrm{t}]-[\mathrm{d}]$ dan $[\mathrm{p}]-[\mathrm{b}]$.

2. Jika suatu bahasa mempunyai konsonan frikatif, bahasa tersebut pasti mempunyai konsonan hambat, Contoh: Jika bahasa $\mathrm{X}$ mempunyai [f] - [v], bahasa ini pun pasti mempunyai [p-b], [t-d], [k-g].

3. Jika suatu bahasa mempunyai konsonan afrikat, bahasa tersebut tentu memiliki konsonan frikatif dan konsonan hambat, contoh: Jika bahasa X mempunyai [ts] dan [d] bahasa ini pasti mempunyai [f-v], [t-d], [k-g]. 
JURNAL PENDIDIKAN USIA DINI

Volume 10 Edisi 2, November 2016

Tabel 1. Urutan Pemerolehan Bunyi Konsonan

Umur 2 Tahun Dardjowidjojo (2000)

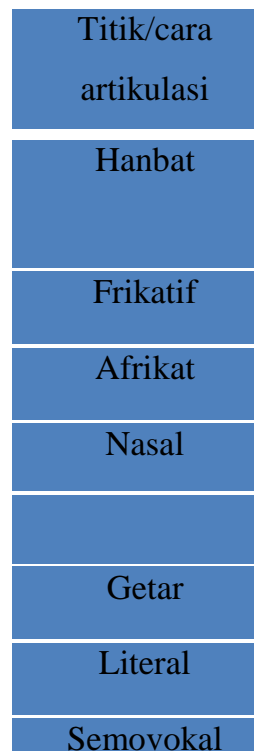

novokal

\begin{tabular}{|c|c|}
\hline Bilabial & Alveolar \\
\hline P & t \\
\hline B & d \\
\hline
\end{tabular}

Alveolar

Palatal

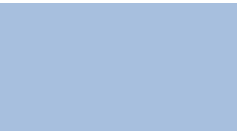

(s)

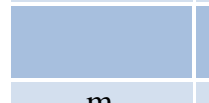

$\mathrm{m}$

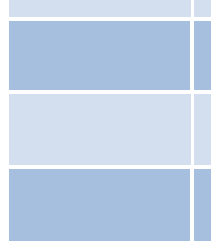

W

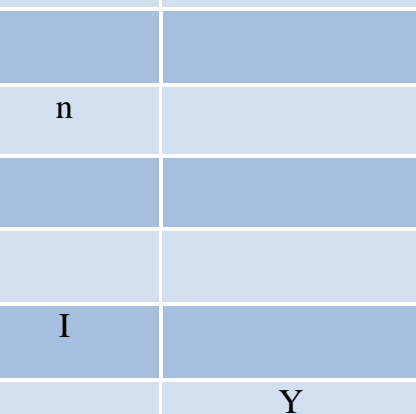

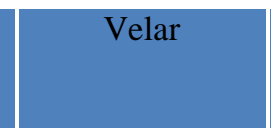

(k)

(g)
Dardjowidjoyo (2000: h. 29)

memvisualisasikan hukum solidaritas

Tak terbalikkan sebagaimana terlihat pada tabel 1 di atas. Pemerolehan bunyi berdasarkan urutannya. Dalam bunyi vokal anak mudah memperoleh lebih awal dibanding dengan vokal-vokal lainnya, demikian pula halnya dengan konsonan yaitu konsonan hambat lebih dahulu diperoleh dibandingkan dengan konsonan frikatif lalu frikatif diperoleh lebih awal dibanding dengan afrikat. Implikasi lain menurut urutan tersebut bahwadalam pemerolehan fonologi anak, anak tersebut belum mampu menguasai afrikat atau frikatif sebelum anak tersebut menguasai konsonan hambat. Dalam masing masing kelompok ada pula urutan pemerolehannya seperti, kontras antara bilabial $\{b\}$ dengan dental $\{d\}$ akan dikuasai lebih awal daripada antara bilabial [b] dengan velar [g] atau dental [d] dengan velar [g]; maka terjadi kontras diantara bilabial-dental [b-d] akan dikuasai oleh anak sebelum bunyi alveopalatal [ts-pd]. Bunyi likuid dan glaid akan dikuasai oleh anak belakangan dan bunyi gugus konsonan dikuasai lebih belakangan lagi. Adapun tingkat kerumitan suatu bunyi diukur 
Pemerolehan Fonology ... Herlina berdasarkan jumlah fitur-fitur yang dikeluarkan bunyi itu dalam satu sistem. Dengan demikian menurut Ingram (1989:27) mengemukakan bahwa bunyi yang diperoleh anak bukan bunyi atau fon secara tersendiri tetapi oposisi-oposisi fonemik (fitur-fitur berkontras). Sistem fonologi anak selalu mempunyai struktur sendiri dan mempunyai persamaan sistematik dengan sistem fonologi orang dewasa dalam bentuk substitusi, dalam tiap tahap perkembangannya.

Dengan demikian pemerolehan fonologi anak menurut teori Ingram $(1987 ; 420)$ berdasarkan ketiga teori tersebut diatas bahwa, pada umumnya anak memperoleh pemerolehan fonologi berdasarkan sistem orang dewasa dengan cara menciptakan atau menirukan strukturnya sendiri dan akan merubah struktur itu apabila pengetahuannya mengenai sistem orang dewasa semakin baik atau dapat diiktuti ujarannya.

\section{METODOLOGI PENELITIAN}

Di dalam penelitian ini, digunakan metode penelitian kualitatif dengan tehnik naturalistik karena memfokuskan perhatian pada situasi kehidupan nyata. Pada awalnya peneliti mengamati Aisyah dengan mengamati pola asuh yang diterapkan ibunya di dalam memberikan pendidikan yang dilakukannya terhadap anakanaknya dan juga membuat perekaman bagaimana Aisyah mengungkapkan kata-kata di dalam pemerolehan fonologinya disamping catatan -catatan ungkapan-ungkapan yang terjadi pada situasi di dalam keluarganya. Adapun yang dicatat adalah kata-kata yang dapat diujarkan sehari-hari selama Aisyah bermain dengan saudaranya, ibunya, dan juga dengan temannya selama pengambilan data dalam penelitian ini.

Data Penelitian dikumpulkan melalui catatan harian yaitu dengan cara mencatat dan mengamati bunyibunyi ujaran yang dikeluarkan oleh Aisyah pada aktifitas dalam seharihari seperti ketika bermain sendirian ataupun bermain dengan kakaknya. Peneliti merekam perkembangan fonologinya yang menjadi subjek pokok yang diteliti dengan 
mengamati kalimat yang pemerolehan fonologi anak yang diungkapkan kegiatan sehari-hari, diteliti.

hal ini berlangsung kurang lebih dua bulan.

Teknik untuk pemeriksaan keabsahan data dengan menggunakan teknik triangulasi. Adapun teknik triangulasi ini terdiri dari empat jenis menurut Moleong (1993:178) yaitu: triangulasi sumber, teori, metode dan penyidik. Dalam penelitian ini hanya menggunakan triangulasi sumber. Instrumen yang digunakan yaitu peneliti sendiri dan dibantu oleh ibunya Aisyah untuk memberi beberapa stimulus dan respon kepada Aisyah sebagai subyek penelitian, sedangkan catatan harian dilapangan sebagai instrumen pelengkap. Ada dua bagian dalam menganalisis data. Pertama, data dianalisis untuk mengetahui unsurunsur fonologi (vokal dan konsonan) yang muncul pada pemerolehan fonologi anak (Aisyah) umur 2;2 (dua tahun dua bulan). Kedua, setelah menganalisis kemudia di diskripsikan berdasarkan data yang disajikan sehingga mengetahui

Penelitian ini bertujuan untuk mengetahui informasi tentang pemerolehan bahasa khususnya perkembangan fonologi anak usia dua tahun dua bulan. Penelitian ini dilaksanakan pada keluarga WH dan AZ. Mereka memiliki dua orang anak yang yaitu AN laki-laki berusia 5 tahun, anak kedua AP perempuan berusia 2;2 tahun. Mereka memiliki status sosial ekonomi yang cukup baik. Ayah mereka Wiraswasta, ibunya sedang menempuh pendidikan pascasarjana (S2) di Fakultas Kedokteran Universitas Brawijaya Malang. Ibunya mendidik anak mereka dengan penuh kasih sayang dan juga didukung dengan tinggal dilingkungan kompleks perumahan dosen Universitas Brawijaya Malang.

\section{HASIL PENELITIAN DAN}

PEMBAHASAN

Berdasarkan

hasil pengamatan, pada umur dua tahun dua bulan, Aisyah sudah banyak menghasilkan serta mengujarkan 
Pemerolehan Fonology . . .

Herlina

berbagai macam fonem sehingga bermain, dan tidur. Semua kegiatan Aisyah dapat membedakan arti kataini diucapkan secara spontan.

kata yang telah diucapkannya.

Kalimat-kalimat ini sering

diungkapkan di dalam kegiatan apa

saja, seperti Aisyah mau makan,

Tabel 2. Bunyi Vokal Aisyah Usia 2 Tahun 2 Bulan.

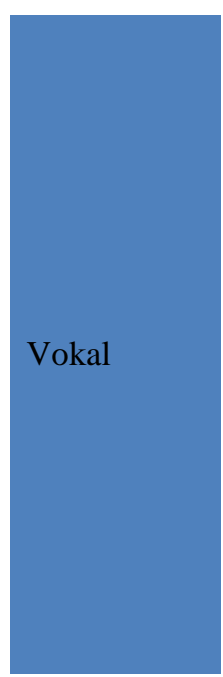

$\begin{array}{lll}\text { [a] } & \text { ayu } & \text { [nama teman] } \\ \text { anan } & \text { [nama kakak] } \\ \text { atu } & \\ \text { ail } & \\ \text { ambi } & \\ \text { ama } & \\ & \end{array}$

\section{'ayu'} 'annan' 'satu' 'air' 'ambil' 'sama'

[i] nni

'ini'

bica

'bisa'

inta

ttu

ilang

[u] wang

ua

udu

'minta'

'itu'

'hilang'

'uang'

'dua'

'duduk'

bulung

'burung'

cucu

'susu'

\section{[O] bobo \\ 'bobo'}

Oto

Ombok

'cabe'

Ongkar 'bongkar'

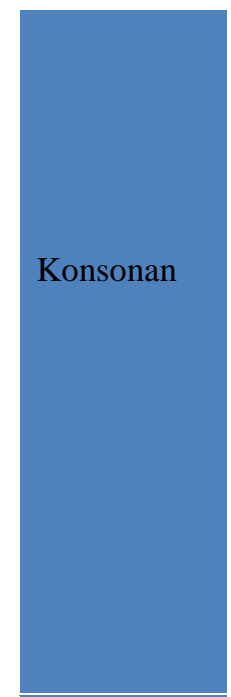

[P] papa, pohon

[b] buang

[t] tulang

[d] udu

[m] mau, mama

[n] ndi

[s] bis

[h] halum

[I] ilang

[y] ayam

[w] cawat

[c] cucu

'papa' 'pohon'

'buang'

'tulang ikan'

'duduk'

'mau' 'mama'

'mandi'

'habis'

'harum'

'hilang'

'ayam'

'pesawat'

'susu'

Reduplikasi

[ati-ati]

[lali-lali]

[ompa-ompa]

[udu-udu]

\section{'hati-hati \\ 'lari-lari \\ 'lompat-lompat' \\ 'duduk-duduk'}

Pada tabel diatas dalam usia dua

tahun dua bulan Aisyah hampir 
menguasai semua fonem vokal dapat menghasilkan berbagai konsonan meskipun belum sempurna. Di samping seperti pada tabel dibawah ini. bunyi vokal dikuasainya, Aisyah juga

Tabel 3. Bunyi Konsonan Aisyah Usia 2 Tahu 2 Bulan

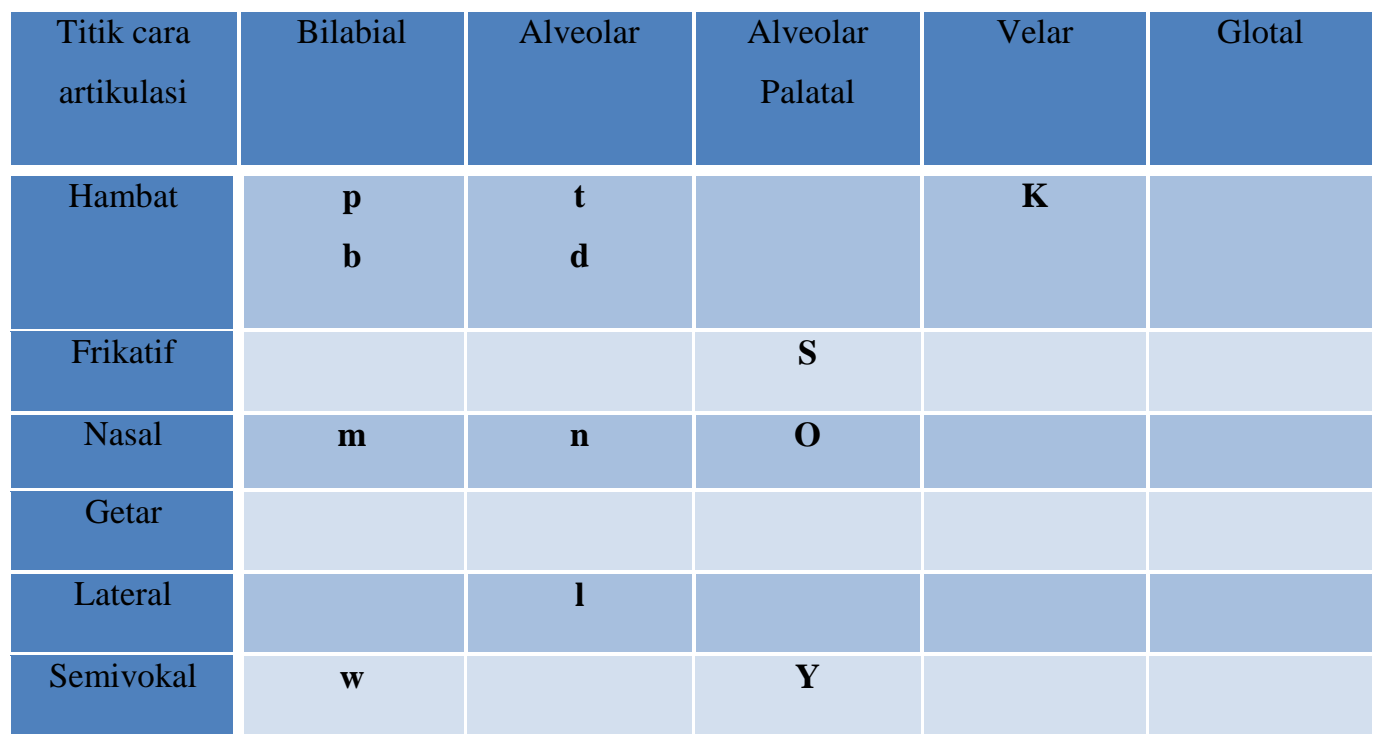

dan memproduksi bermacam-macam

\section{Deskripsi Data}

Berdasarkan data yang diperoleh dari subjek peneliti bahwa semua bunyi vokal sudah muncul, pada bunyi konsonan belum semua muncul dan kadang-kadang ada bunyi konsonan di awal kalimat dihilangkan, ada pula bunyi konsonan yang diganti dengan konsonan lainnya. Data diatas menunjukkan perkembangan bahwa dengan umur dua tahun dua bulan, Aisyah sudah banyak mengetahui fonem yang bisa membedakan berbagai macam arti kata-kata yang diucapkannya. Kesanggupan mengucapkan pemerolehan fonologi Aisyah masih sekitar bunyi-bunyi vokal /m/, p / pada kata /mami/ dan /papi/. Kalimat ini sering diungkapkan ketika memanggil ibu dan ayahnya ketika sedang bermain di dalam rumah atau dalam situasi dimanapun ketika bersama orang tuanya, seperti ketika mau makan, mau tidur, mau mandi, ketika rewel 
Pemerolehan Fonology . . . Herlina dan semua kata-kata ini diungkapkan secara spontan.

Konsonan hambat bilabial [p] sudah muncul pada kata [pohon], kalimat ini muncul ketika ibunya membersihkan halaman sekitar rumah.

Ibu : “Aisyah, jangan kesini pohon jambu banyak semutnya”.

Aisyah : "Pohonnya, anyak cemut?" [Pohon jambu banyak semutnya] Aisyah meniru kembali kata pohon yang diucapkan ibunya.

Ibu : "Aisyah mandi baru nonton yah?"

Aisyah: "Mmau (tidak mau) sambil berlari kedalam rumah".

Ibu : "Aisyah mau makan apa?" Aisya : "Yam ... goleng, dengan suara agak keras".

Bunyi hambat bilabial (b) dapat diujarkan dengan jelas misalanya kata [buang] 'Buang' kata ini muncul ketika Aisyah sedang makan pisang dan senang membuang kulitnya sendiri ke tempat sampah, bunyi hambat alveolar yaitu [t] sudah muncul baik pada awal, tengah dan akhir kata seperti kata [ati - ati] 'Hati-hati' ketika melihat kakaknya mewarnai buku gambar dengan krayon dan mengungkapkan kata 'Ati-ati layonnya patah'. Pada bunyi konsonan hambat alveolar [d] sudah muncul walaupun terdengar belum jelas, pada saat bermain dengan temannya di teras rumah, Aisyah mengajak temannya, 'Dudu di cini' [duduk di sini] sambil menarik tangan temannya untuk melihat gambar yang sudah di warnai oleh kakaknya. Aisyah mengucapkannya dengan menghilangkan konsonan hambat velar [k] yang berada pada akhir kata 'duduk'

Bunyi nasal bilabial [m] sudah kedengaran seperti [mam] 'makan', 'Mama mau mam' [makan], 'Mama mau makan'. Sedangkan kata [ayam] muncul ketika Aisyah ditanya mau makan apa? 'Yam'. Bunyi nasal alveolar [n] sudah kedengaran jika berada di tengah dan akhir kata seperti pada kata [alontu] 'balonku' ketika Aisyah menghadiri acara ulang tahun temannya dan menyayikan lagu 'balonku' 'Alontu ada ua, lupa-lupa warnanya' dst.

Bunyi nasal velar [ $\eta$ s sudah mulai kedengaran walaupun masih sedikit dan bila berada di tengah dan 
akhir kata misalnya pada kata [anan] 'jangan', [bu:luך] 'burung', [endoך] 'gendong'. Konsonan frikatif [s] sudah muncul walaupun baru pada akhir kata seperti [pis] 'pipis'. [abis] 'habis' ketika Aisyah selesai minum susu, minum susu masih menggunakan dot sambil berbaring jika botol susunya sudah kosong Aisyah mengucapkan [abis] 'habis',

Didalam pemerolehan bunyi frikatif glotal $[\mathrm{h}]$ baru terdengar pada akhir kata seperti [Ombuh] 'sembuh' [utih] 'putih'. Bunyi getar [r] belum muncul dan sering diganti dengan lateral [1] seperti pada kata [bulung] 'burung', tetapi kadangkadang muncul bunyi getar [r] bila berada d akhir kata seperti pada kata [ular] 'ular'. Bunyi semivokal alveopalatal [y] sudah mulai kedengaran walaupun masih jarang dan jika berada di tengah seperti pada [ ayam] 'ayam'. Bunyi semivokal bilabial [w] sudah kedengaran walaupun jika berada pada tengah kata seperti pada [ awat] ' pesawat'. Bunyi frikatif velar [x] belum muncul maka kata [olong] 'tolong' [ aksi] 'taxi' dia mengganti bunyi frikatif velar $[\mathrm{x}]$ dengan bunyi afrikat $[\mathrm{s}]$.

$$
\text { Reduplikasi sudah mulai }
$$
kedengaran walaupun jumlahnya masih sedikit seperti pada saat peneliti membawa Aisyah ke Jakarta dan membawa jalan jalan ke ancol melihat pertunjukan lumba-lumba, Aisyah menunjuk ke lumba-lumba

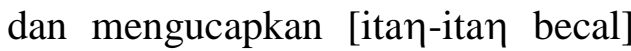
'ikan-ikan besar' maksudnya lumbalumba, peneliti memberitahu bahwa itu ikan lumba-lumba Aisyah mengikuti ucapan peneliti [itang lumba-lumba]. Hal ini tidaklah diragukan karena perkembangan kinestik, perkembangan komprehensi, dan perkembangan fonologi Aisyah akan terus berkembang.

Ditinjau dari segi fonologi fonem-fonem yang dikuasai oleh anak pada awal pemerolehan fonologi ternyata berhubungan erat dengan perkembangan neurofisiologi anak, proses tahap-tahap perkembangan, maupun unsur-unsur bahasa yang sedikit demi sedikit dikuasai oleh anak sehingga dapat 
Pemerolehan Fonology ... Herlina dikatakan bahwa pemerolehan bahasa itu bersifat universal.

\section{Pemerolehan}

fonologi

khususnya bunyi konsonan hambat bilabial [p] pada posisi awal dan tengah, bunyi hambat bilabial lainnya yaitu [b] sudah dibunyikan dengan jelas oleh Aisyah. Bunyi hambat alveolar yaitu [t] sudah muncul, sedangkan bunyi hambat alveolar lainnya [d] sudah dibunyikan dengan jelas. Jadi bunyibunyi konsonan tersebut diatas sesuai dengan teori Jacobson (2000;21) yang mengatakan bahwa dengan adanya persamaan dalam suatu bunyi-bunyi bahasa tertentu itu sesuai dengan bagian-bagian pemerolehan bahasanya. Anak memperoleh bunyi-bunyi itu melalui suatu cara yang konsisten dan pemerolehan bunyi pun berjalan serasi dengan kodrat bunyi itu sendiri. Bunyi-bunyi konsonan tersebut sudah mulai muncul pada anak umur 2,0. Bunyi nasal bilabial [m] muncul pada semua posisi baik di awal, tengah, maupun di akhir kata. Begitu pula bunyi nasal alveolar [n] sudah kedengaran walaupun berada di tengah dan di akhir kata, Bunyi nasal velar [ $\eta]$ sudah mulai kedengaran pada beberapa kata apabila berada di tengah dan akhir kata. Semivokal alveopalatal [y] dan bunyi semivokal bilabial [w] sudah mulai kedengaran apabila berada di tengah kata dan jumlahnya masih sedikit. Hal ini dapat terjadi karena pemerolehan leksikon yang mengandung kedua bunyi konsonan tersebut masih sangat terbatas untuk anak yang baru berusia dua tahun dua bulan karena pemerolehan fonologi sangat berkaitan dengan pemerolehan leksikon.

\section{KESIMPULAN}

Setelah menganalisis dari hasil data diperoleh bahwa pemerolehan bahasa dalam pemerolehan fonologi pada anak umur dua tahun dua bulan khususnya Aisyah sebagai subjek penelitian, pemerolehan fonologi Aisyah berkaitan erat dengan pemerolehan leksikon.

Dari data yang diperoleh ada bunyi yang muncul karena meniru ucapan orang dewasa dan ada juga bunyi yang muncul dari kata yang 
diperoleh setelah melihat bendanya, kemudian ada yang muncul secara spontan sesuai dengan situasi atau muncul karena kegiatan yang sering dilakukan oleh Aisyah di lingkungan sekitarnya sehingga sudah pernah mengalaminya, berlanjut atau tidaknya suatu bunyi untuk menjadi bagian dari fonologi yang diterima anak memang ditentukan oleh masukan yang diterima oleh anak itu sendiri. Masukan-masukan inilah yang dapat menentukan bahasa mana yang akhirnya diperoleh oleh anak tersebut.

Pada umur dua tahun dua bulan pemerolehan bahasa Aisyah mengalami perubahan dari pemerolehan memproduksi fonologinya, morfologis dan sintaksisnya yang telah dibahas dalam pembahasan. Dalam penelitian pemerolehan fonologi dapat disimpulkan bahwa umur dua tahun dua bulan, Aisyah yang mengalami masa pertumbuhannya Aisyah sudah bisa mengucapkan fonem-fonem yang dapat disesuaikan dengan lingkungannya dan dapat mengucapkan benda-benda disekitar lingkungannya.

$$
\text { Bunyi-bunyi yang }
$$

diungkapkan ada yang sudah muncul dan juga belum muncul pada pemerolehan fonologi. Bunyi-bunyi tersebut berasal dari lingkungan sekitarnya karena bunyi inilah yang menentukan bahwa bahasa yang sedang dikuasai oleh seorang anak datang dari dalam dirinya, artinya dari kemampuan neurofisiologis anak itu sendiri.

Di samping ujaran-ujaran yang telah diperoleh Aisyah didalam pemerolehan fonologinya dalam temuan penelitian ini, maka penelitian ini dapat disimpulkan bahwa seorang anak dalam masa pertumbuhan yang tidak mengalami cacat fisik dan mental (normal) anak itu mampu memperoleh bahasa pertama dan juga jika saraf dan jaringan otak anak tersebut tidak mengalami gangguan dalam pertumbuhannya. Walaupun lingkungan memaksa anak untuk mengucapkan sesuatu, jika program genetiknya belum siap untuk digunakan maka tidaklah mungkin 
Pemerolehan Fonology ... Herlina anak dapat melakukannya, walaupun demikian bunyi-bunyi yang diperoleh anak tetap saja berasal dari lingkungannya.

Didalam perkembangan kejiwaan, peranan gizi yang telah dikomsumsi serta lingkungan sangat berpengaruh dan berperan penting dalam pertumbuhan mental dan fisik serta motorik serta neurologi anak

\section{DAFTAR PUSTAKA}

Chomsky, N. 1975. Reflections of Language. New York: Pantheon Books.

Dardjowidjoyo, Soenjono, 2000. Echa: Kisah Pemerolehan Bahasa Anak Indonesia. (Jakarta: PT Gramedia Widiasarana Indonesia.

Fieldman, R.S. 1997. Essential of understanding Psychology. New York: (McGraw-Hill Companies.

Fletcher,P.\& Garman,M. Language Acquisition.1985.(Cambridge:Ca mbridge University Press,

Gleason, Jean Berco, \& Nan Berstein Ratner (eds) 1998. Psycholinguistics, Forth Worth: (Harcourt Brace College Publishers).

Goodman. Ilana and Lesly Wade. 2010. America's Early Childhood khususnya di dalam pemerolehan dan produksi pemerolehan bahasa anak. Meskipun kecil pengaruhnya dalam ilmu linguistik, di dalam hasil penelitian ini akan terlihat bahwa lingkungan itu sangat berperan penting dalam pemerolehan fonologi bagi anak bersusia dua tahun dua bulan khususnya Aisyah.

(http://www.oregon.gov/ost/LD/y outhsvcs/readinghealthy.families/ Research.AmericasEarlyChildhoo d Literacy Gap.pdf), (diakses 10 Maret 2016).

Gregory, R.J. 2000. Psychological Testing: History, Principle and Application.. Boston:

Ingram, David 1989 First Language Acquisition Method, Description, and explanation.Cambridge University Press,

Ingram, D. and Stern (1989). Phonological disability in children. 2nd Ed. London: Cole and Whurr Ltd.

Kuhl, P., Conboy, B., 2008. Phonetic learning as a pathway to language: New data and native language magnet theory expanded (NLMe). Philosophical Transactions B, 363: 979-1000. 
JURNAL PENDIDIKAN USIA DINI

Volume 10 Edisi 2, November 2016

Lyons John , 1995. Pengantar Teori Linguistik. PT Gramedia Pustaka Utama. Jakarta.

Moleong, Lexy,J. 1993. Metode Penelitian Kualitatif Bandung: PT Remaja Rosdakarya,

Monks,F.J., Knoes,A.M.P, \& Haditono, S.R. 2004. Psikologi perkembangan: Pengantar dalam berbagai bagiannya: Yokyakarta: Gadjah Mada University Press,)

Renzulli, J.S.\& Reis,S. M. 1985. The Schoolwide enrichment model: A comprehensive Plan for Educational Exellence. (New York: Creative

Scarborough , 2008, Developing Early Literacy Report of the National Early Literacy Pane I-A Scientific Synthesis of Early Literacy Development and Implications for Intervention, (http://lincs. ed. gov/ publications/ pdf/ Nelp Report. Pdf). 